Association for Information Systems

AIS Electronic Library (AISeL)

Wirtschaftsinformatik 2021 Proceedings

Track 16: Digital Innovation \& Entrepreneurship

\title{
Digital Innovation Culture: A Systematic Literature Review
}

\author{
Daniel Kiefer \\ ESB Business School, Reutlingen University, Reutlingen, Germany \\ Clemens Van Dinther \\ ESB Business School, Reutlingen University, Reutlingen, Germany \\ Julian Spitzmüller \\ itdesign GmbH, Tübingen, Germany
}

Follow this and additional works at: https://aisel.aisnet.org/wi2021

Kiefer, Daniel; Van Dinther, Clemens; and Spitzmüller, Julian, "Digital Innovation Culture: A Systematic Literature Review" (2021). Wirtschaftsinformatik 2021 Proceedings. 4.

https://aisel.aisnet.org/wi2021/JDigitalInnovation16/Track16/4

This material is brought to you by the Wirtschaftsinformatik at AIS Electronic Library (AISeL). It has been accepted for inclusion in Wirtschaftsinformatik 2021 Proceedings by an authorized administrator of AIS Electronic Library (AISeL). For more information, please contact elibrary@aisnet.org. 


\title{
Digital Innovation Culture: A Systematic Literature Review
}

\author{
Daniel Kiefer ${ }^{1}$, Clemens van Dinther ${ }^{1}$, and Julian Spitzmüller ${ }^{2}$ \\ ${ }^{1}$ ESB Business School, Reutlingen University, Reutlingen, Germany \\ \{Daniel.Kiefer,Clemens.Van_Dinther\}@Reutlingen-University.de \\ 2 itdesign $\mathrm{GmbH}$, Tübingen, Germany \\ \{Julian.Spitzmueller\}@itdesign.de
}

\begin{abstract}
Digitalization increases the pressure for companies to innovate. While current research on digital transformation mostly focuses on technological and management aspects, less attention has been paid to organizational culture and its influence on digital innovations. The purpose of this paper is to identify the characteristics of organizational culture that foster digital innovations. Based on a systematic literature review on three scholarly databases, we initially found 778 articles that were then narrowed down to a total number of 23 relevant articles through a methodical approach. After analyzing these articles, we determine nine characteristics of organizational culture that foster digital innovations: corporate entrepreneurship, digital awareness and necessity of innovations, digital skills and resources, ecosystem orientation, employee participation, agility and organizational structures, error culture and risk-taking, internal knowledge sharing and collaboration, customer and market orientation as well as openmindedness and willingness to learn.
\end{abstract}

Keywords: Digital, Innovation, Culture, Organization, Transformation

\section{$1 \quad$ Introduction}

Many companies are still overwhelmed by digital transformation, in particular when it comes to proactive behavior and discussing its actual impact and potentials for companies [1]. Innovation has always played a crucial role for competitive advantage and corporate success $[2,3]$. It can be used to adapt to changes in the business environment and to meet customer needs [4]. Likewise, the requirements for innovations have changed over the past few years: the increased intensity of competition, technological development and changing customer needs result in shortened product lifecycles [5]. Consequently, there is increased pressure to create innovations in companies in a more effective and efficient way.

Creating these innovations in the digital era is a serious challenge for companies that cannot be solved easily. Innovation culture is mentioned as a key driver to manage digital transformation [6]. New digital products, services, business models or ecosystems need an organizational culture that creates and fosters these digital innovations [7]. Therefore, many companies have already introduced new concepts and

16th International Conference on Wirtschaftsinformatik,

March 2021, Essen, Germany 
methods such as agile project management or design thinking in order to encourage digital innovations. However, in order to manage its digital transformation and to be successful and innovative in the digital age, a company might need much more than just a digital strategy and the usage of new technology and methods. Changing the organizational culture in favor of the digital transformation implies a radical change in the way people think, behave and collaborate in companies, how they generate ideas and how they make decisions.

Nevertheless, the concrete design of a digital innovation culture and its characteristics are still unclear [8-10]. Research on both organizational and innovation culture has a long tradition and offers a variety of definitions, models and studies [5, 11]. However, current research does not consider the changes due to digitalization that were mentioned in the beginning of this article. Moreover, most research of digital transformation focuses on the technological or economical aspects (such as business model innovation or ecosystems) and miss out on the cultural aspect [12]. But organizational culture has always been a high obstacle for business transformations and many sophisticated strategies have failed to overcome this obstacle.

Only [9] and [10] address the topic of digital innovation in the context of organizational culture. [9] conducted a Delphi study in where he interviewed participants from companies to identify cultural values for digital transformation. [10] collected data through exploratory case studies and pictured it on culture levels from [13] (e.g. artifacts). But both lack of general expressiveness regarding digital innovation culture. This is due to the limited method of the studies and the small frame of reference ([9]interviewed twenty five German employees from various industries and [10] analyzed German case studies). This shows that the topic has received little attention in the scientific community so far. [14] recently noted: "that because of the shift in the locus of innovation and because some of our core organizing axioms may be challenged or fundamentally changed by the digital revolution, the nature of innovation and organizational scholarship may be at a transition point."

This is why, we strongly believe that digitalization will change more than products, technologies, processes and strategies. To a greater extent and starting one step prior, we think that companies will nurture ongoing digital innovations by creating a suitable organizational culture. Consequently, we are exploring the characteristics of organizational culture that benefit digital innovations. This leads to the following research question:

- RQ: What characteristics should an organizational culture have to foster digital innovations?

To answer this research question, we have conducted a systematic literature review. The structure of the paper is as follows: First, the theoretical context of innovation, organizational culture and digital transformation is explained. Second, the literature review, its methodology and its results are presented. Third, we discuss the results and limitations of the literature review as well as its implications for future research. 


\section{Theoretical Context and Boundaries}

As outlined in the introduction, the three aspects "Innovation", "Digital Transformation" and "Organizational Culture" form the context of our research (Figure 1). The innovation aspect deals with the question of how innovations can be fostered. Digital transformation determines the context in which these innovations happen. Organizational culture addresses the practiced patterns, approaches and values in form of characteristics. Finally, "Digital Innovation Culture" is the subject of our research. In the following section, we will briefly define these terms.

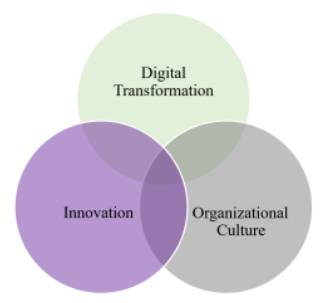

Figure 1. Overall context of digital innovation culture

Innovation refers to the usage of novel ideas, products, services, processes that are new to the implementing organization and create an advantage for the organization [4].

Digital transformation describes the transformation of organizations that is based on the usage of digital technology and radically changes business operations and value creation [15]. According to [16], digital innovations are characterized as "the carrying out of new combinations of digital and physical components to produce novel products". As we do not see digital innovations limited to products only (e.g. services and business models), we define digital innovations as innovations that are enabled by digital technologies.

Following [13], organizational culture is "a pattern of shared basic assumptions that was learned by a group as it solved its problems of external adaptation and internal integration, that has worked well enough to be considered valid and, therefore, to be taught to new members as the correct way to perceive, think, and feel in relation to those problems". Moreover, [13] provides a model to describe and analyze organizational culture which consists of three levels: artifacts, espoused beliefs and values as well as underlying assumptions. Whereas artifacts are characterized as being observable (e.g. organizational structures, processes, clothing, and stories), espoused beliefs and values deal with the strategies, goals, norms and moral principles in an organization. Underlying assumptions are beliefs that are taken-for-granted and unconscious. They are widely accepted within an organization and people do not question them anymore.

These three aspects set our research boundaries for the literature review and explain the context of our search. By looking at the overlap of all three aspects (Fig. 1), we can clarify the construct "Digital Innovation Culture". Consequently, we define digital innovation culture as an organizational culture that fosters digital innovations. 


\section{$3 \quad$ Research Method}

In order to identify how a digital innovation culture looks like, we followed the approach for literature reviews suggested by [17, 18]. Fig. 2. illustrates the seven-step search process that was conducted as part of this literature review to identify characteristics that foster a digital innovation culture.

The actual literature search process was started after the framework conditions were set within the first and second step according to the defined research question from chapter 1 . The extraction $\log$ is the basis of the literature search. All necessary information is stored in it and which is used for the final matrix. The matrix consists of articles that are considered relevant. Based on these articles the research question is answered step by step. The keyword search process (step 3) consists of several iterations. The actual analysis and evaluation of the literature consists of the title and abstract analysis (step 4) as well as the full text analysis (step 5). The result is the final extraction log, which is used as the basis for the matrix. It should be emphasized that forward and backward searches were also part of the literature search strategy in this contribution (step 6). The results of the individual process steps as well as the number of identified articles after the various search iterations are presented in the following chapters.

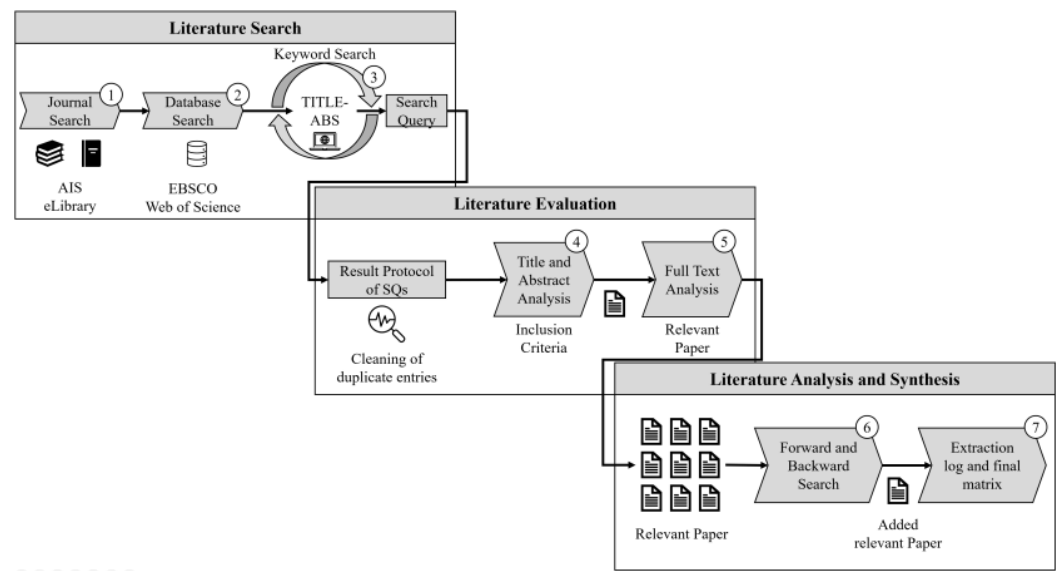

Figure 2. Process of literature research $[17,18]$

\subsection{Literature Search}

Based on the research question formulated in chapter 1, first articles were collected in journals and databases to derive suitable keywords for the search query. The aspects from Fig. 1 were also used to derive relevant keywords for the comprehensive search. Digital innovation is an emerging research field, which is why we also included IS conference proceedings of the AIS eLibrary. Our search is limited to peer-reviewed articles $^{1}$.

1 As we received few results in the AIS eLibrary, we also included non-peer-reviewed articles of this database only. 
We conducted our search in July and August 2020 on the scholarly databases EBSCO and Web of Science, which are recommended by [19-21]. The search was focused on the "title" and "abstract" fields. The language of the articles is limited to English and German. Our final search query is as follows:

$$
\begin{gathered}
\left.\left(\text { digit }^{*}\right) \text { AND (innovat } * \text { OR creativ } *\right) \text { AND (cultur } * \text { OR organization) AND } \\
\text { (compan* or firm or business) }
\end{gathered}
$$

\subsection{Literature Evaluation}

By following these steps, our search resulted in an initial set of 778 contributions.

After removing duplicates (82) and articles in other languages than English and German (58), we had 683 remaining articles.

In the next phase the contributions were analyzed of their suitability based by their title. We were able to exclude most of these articles when we went through the titles. By analyzing their abstracts and conclusions we had a closer look whether they could help to answer our research question. After we went through the articles, a finding was that that many articles deal with the impact of digitalization on national culture or on culture industry. Another area was e-government. Those papers were excluded from the analysis because the focus lies on companies (see selection criteria 3.2).

After this stage, 123 potentially relevant articles remained which were then read carefully in the fourth phase of our selection (see literature analysis process in Fig. 3).

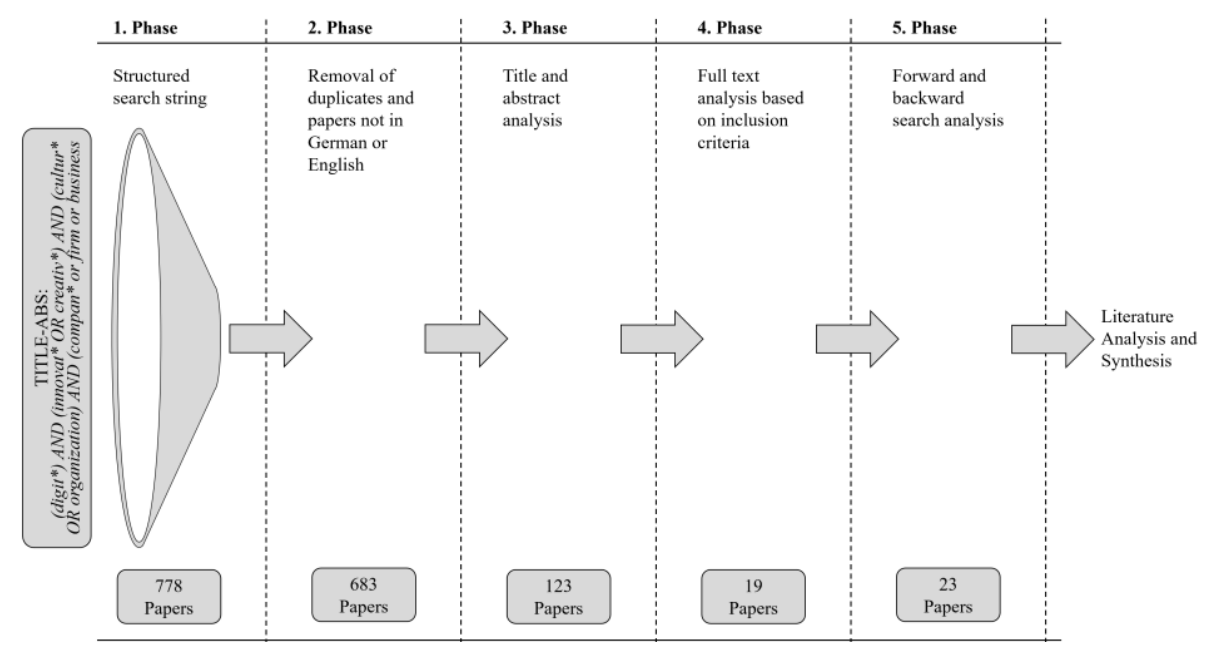

Figure 3. Resulting papers from the literature analysis process

For the selection of the encountered and remaining articles, we established the following inclusion criteria, whereby all three must be fulfilled:

1. Articles must have a focus on digital transformation.

2. Articles must address digital innovation.

3. Articles must deal with organizational culture in companies or at least parts of it. 
Those inclusion criteria reduced the number of articles to 19. Finally, a forward and backward search lead to four additional articles which makes 23 relevant contributions in total.

\subsection{Literature Analysis and Synthesis}

The relevant 23 articles were analyzed with regard to our research question. Fig. 4 illustrates the procedure based on the recommendations of [17].

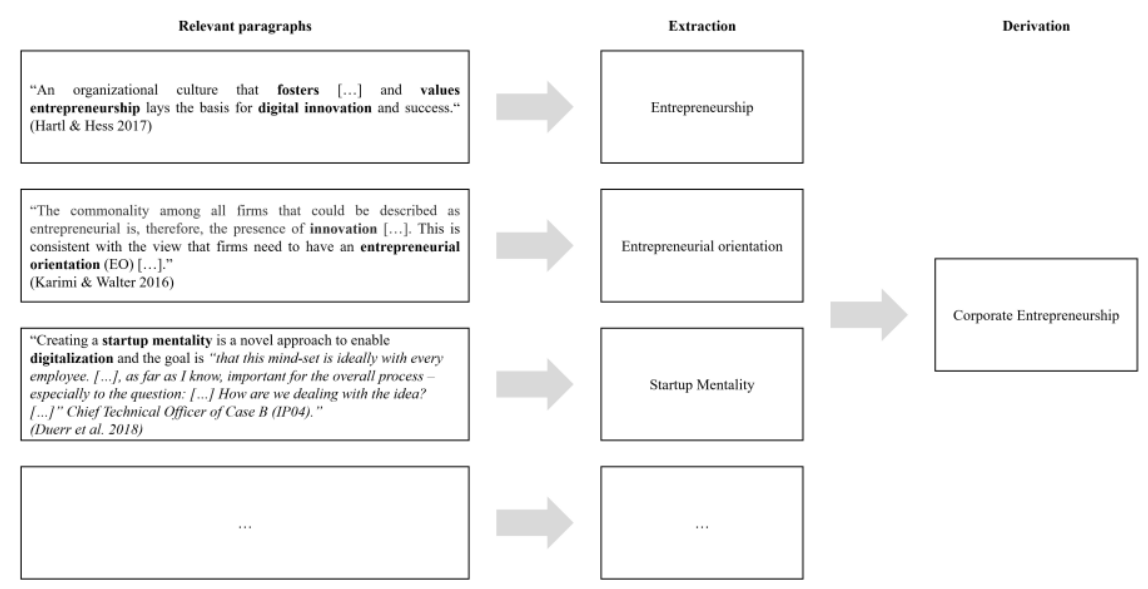

Figure 4. Exemplary illustration of the literature analysis and synthesis based on [17]

As a first step, all 23 articles were carefully read again and the aspects or characteristics described or mentioned by the authors, which promote a digital innovation culture, were listed in a table ${ }^{2}$ with 108 entries at the end.

In a second step the characteristics considered important, which were listed in the table, were compared with each other. It became apparent that the different authors use different names for the same relevant characteristics (e.g. entrepreneurship [9], entrepreneurial orientation [22] and startup mentality [10], etc.).

In a third iterative step, the equivalent entries - key aspects of the articles to foster digital innovation culture - were classified, clustered and unified in categories (characteristics). As an output nine characteristics of organizational culture that were in some way considered important for a digital innovation culture in the articles were derived.

In a fourth step, a matrix was developed that shows which article mentions specific characteristics relevant to the fostering of a digital innovation culture (Table 1, Chapter 4). It should be taken into account that based on the sole frequency of naming a characteristic, no evaluation can be made with regard to its importance compared to the other characteristics. This is a core task for further research to conduct extensive studies to measure the relevance of the individual characteristics.

2 MS Excel, a spreadsheet application, was utilized for the literature analysis and synthesis process. 


\section{Results of the Literature Review}

Table 1 compromise the results of the literature analysis and synthesis based on [17] and gives an overview of the unified characteristics as well as in which paper they are discussed (marked by " $x$ " if mentioned in the respective article).

Table 1. Result of the literature review: mentioned characteristic per paper

\begin{tabular}{|c|c|c|c|c|c|c|c|c|c|c|}
\hline \multicolumn{11}{|c|}{ Characteristic of organizational culture to foster digital innovation } \\
\hline Paper & 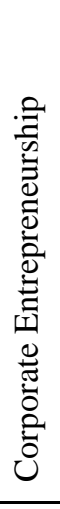 & 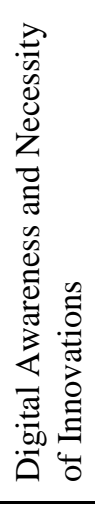 & 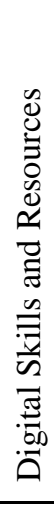 & 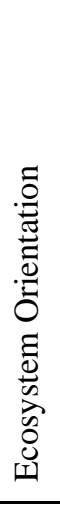 & 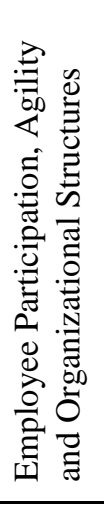 & 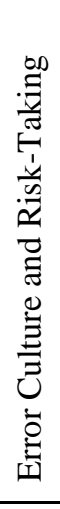 & 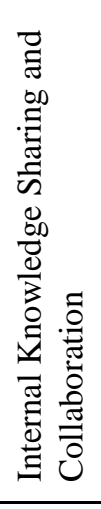 & 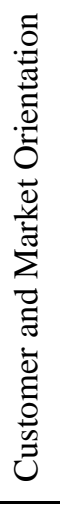 & 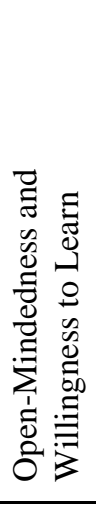 & Sum \\
\hline [8] & & $\mathrm{x}$ & $\mathrm{x}$ & $\mathrm{x}$ & & $\mathrm{X}$ & $\mathrm{x}$ & $\mathrm{x}$ & $\mathrm{x}$ & 7 \\
\hline [9] & $\mathrm{x}$ & $\mathrm{x}$ & & $\mathrm{x}$ & $\mathrm{x}$ & $\mathrm{x}$ & $\mathrm{x}$ & $\mathrm{x}$ & $\mathrm{x}$ & 8 \\
\hline [10] & $\mathrm{x}$ & $\mathrm{x}$ & $\mathrm{x}$ & $\mathrm{x}$ & $\mathrm{x}$ & $\mathrm{x}$ & $\mathrm{x}$ & $\mathrm{X}$ & & 8 \\
\hline [22] & $\mathrm{x}$ & & & & $\mathrm{x}$ & $\mathrm{X}$ & & & $\mathrm{x}$ & 4 \\
\hline [23] & $\mathrm{x}$ & $\mathrm{x}$ & $\mathrm{x}$ & & $\mathrm{x}$ & $\mathrm{X}$ & & & $\mathrm{x}$ & 6 \\
\hline [24] & & $\mathrm{x}$ & $\mathrm{x}$ & $\mathrm{x}$ & & & & $\mathrm{X}$ & & 4 \\
\hline [25] & & & & & & & & $\mathrm{X}$ & & 1 \\
\hline [26] & & $\mathrm{x}$ & & & $\mathrm{x}$ & & $\mathrm{x}$ & & & 3 \\
\hline [27] & & $\mathrm{x}$ & & $\mathrm{x}$ & $\mathrm{x}$ & & $\mathrm{x}$ & $\mathrm{x}$ & $\mathrm{x}$ & 6 \\
\hline [28] & & $\mathrm{x}$ & $\mathrm{x}$ & $\mathrm{x}$ & & & & $\mathrm{x}$ & $\mathrm{x}$ & 5 \\
\hline [29] & & & $\mathrm{x}$ & & $\mathrm{x}$ & $\mathrm{x}$ & $\mathrm{x}$ & & $\mathrm{x}$ & 5 \\
\hline [30] & & & $\mathrm{x}$ & & $\mathrm{x}$ & & & $\mathrm{X}$ & $\mathrm{x}$ & 4 \\
\hline [31] & & $\mathrm{x}$ & & $\mathrm{x}$ & $\mathrm{x}$ & & $\mathrm{x}$ & & & 4 \\
\hline [32] & $\mathrm{x}$ & $\mathrm{x}$ & $\mathrm{x}$ & $\mathrm{x}$ & $\mathrm{x}$ & $\mathrm{x}$ & & & & 6 \\
\hline [33] & & $\mathrm{x}$ & $\mathrm{x}$ & & $\mathrm{x}$ & $\mathrm{X}$ & $\mathrm{x}$ & & $\mathrm{x}$ & 6 \\
\hline [34] & $\mathrm{x}$ & & $\mathrm{x}$ & & $\mathrm{x}$ & & $\mathrm{x}$ & $\mathrm{x}$ & $\mathrm{x}$ & 6 \\
\hline [35] & & $\mathrm{x}$ & $\mathrm{x}$ & & $\mathrm{x}$ & $\mathrm{x}$ & & $\mathrm{x}$ & $\mathrm{x}$ & 6 \\
\hline [36] & $\mathrm{x}$ & $\mathrm{x}$ & & $\mathrm{x}$ & & $\mathrm{x}$ & $\mathrm{x}$ & $\mathrm{X}$ & $\mathrm{x}$ & 7 \\
\hline [37] & & & $\mathrm{x}$ & & $\mathrm{x}$ & $\mathrm{x}$ & & & $\mathrm{x}$ & 4 \\
\hline [38] & $\mathrm{x}$ & & $\mathrm{x}$ & $\mathrm{x}$ & $\mathrm{x}$ & & & & $\mathrm{x}$ & 5 \\
\hline [39] & & $\mathrm{x}$ & $\mathrm{x}$ & & $\mathrm{x}$ & & $\mathrm{x}$ & $\mathrm{X}$ & & 5 \\
\hline [40] & & $\mathrm{x}$ & $\mathrm{x}$ & & $\mathrm{x}$ & $\mathrm{x}$ & $\mathrm{x}$ & $\mathrm{X}$ & $\mathrm{x}$ & 7 \\
\hline [41] & & & $\mathrm{x}$ & $\mathrm{x}$ & $\mathrm{x}$ & $\mathrm{X}$ & $\mathrm{x}$ & $\mathrm{x}$ & $\mathrm{X}$ & 7 \\
\hline Sum & 8 & 15 & 16 & 11 & 18 & 13 & 13 & 14 & 16 & \\
\hline
\end{tabular}


The following figure 5 visualizes the results from table 1 graphically. Based on the number of entries and the sum of the relevant articles, a percentage of the frequency distribution of the respective organizational culture characteristic is calculated. This does not reflect the importance of the characteristic in the organization compared to the others, but shows which ones have been mentioned particularly frequently to foster digital innovation. The result could be used in assessments to benchmark and display the profile of the digital innovation culture of single organizations.

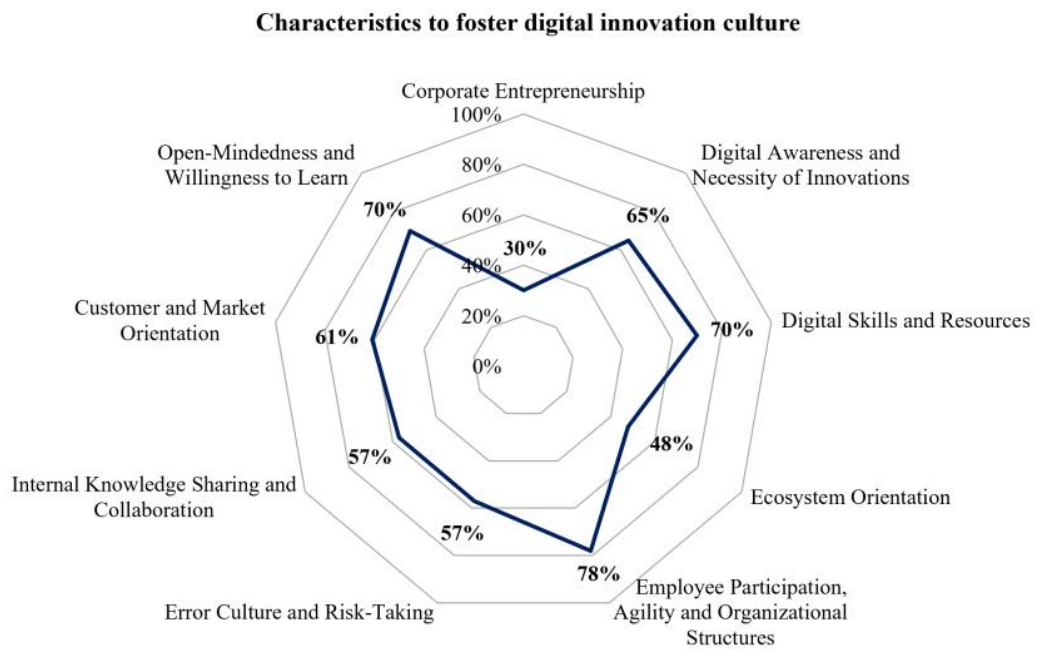

Figure 5. Characteristics to foster digital innovation culture

\subsection{Corporate Entrepreneurship}

Corporate Entrepreneurship was mentioned several times in the relevant articles. In order to stay ahead of competitors, to be first to market and to grow, companies must proactively identify new business opportunities [36]. Therefore, it is helpful to encourage employees to find these new business opportunities [22]. Ideally, all employees should become entrepreneurs [10,23] This requires a shift of responsibilities towards employees and also giving them more freedom and foster a digital innovation culture $[9,34]$.

\subsection{Digital Awareness and Necessity of Innovations}

Another important characteristic is the awareness in the company regarding digital transformation, its impact, threats and opportunities as well as the need for innovations. This awareness begins at top management level [28, 33]. It is important that digital transformation is taken seriously and that a clear strategy and mission contribute to a common understanding within the company, stress the importance of digital transformation and encourage employees to come up with new ideas and business opportunities [27, 31, 32, 40] Putting that in one sentence: "True change needs true 
authenticity" [40]. So, using new technologies or setting up innovation labs as an alibi without a real purpose is not enough to become truly digital and innovative within the digital transformation [35]. The necessity of innovations should be anchored in the organizational culture of a company because innovation is one way for a company to grow and to make improvements [9].

\subsection{Digital Skills and Resources}

Creating digital innovations requires several skills and resources. Companies might want to evaluate employees' technological competencies and offer opportunities to enhance these competencies, develop completely new ones or hire new employees with the wanted skills. In this context, it should be noted that some companies overestimate their competencies, especially in the digital area. Missing resources and skills can also be obtained from external partners in an ecosystem [10, 29, 30, 34, 40].

Looking at hard skills, data management and data analytics as well as several associated domains (e.g. artificial intelligence, machine learning and statistical modelling) were mentioned very often in the relevant articles for a successful digital transformation [24, 38, 39, 41]. Besides these hard skills, soft skills are important, too. Especially change management skills are useful [23].

\subsection{Ecosystem Orientation}

Innovations sometimes need external partners [27]. As resources and knowledge of companies are limited [41], it might be useful to search for complementary capabilities outside the company [36]. For example, traditional manufacturing companies could therefore partner up with IT firms to equip products with digital components [10]. Digital platforms enable a value creation with other companies in digital ecosystems or networks [32]. Especially when building end-to-end solutions for customers, an open innovation approach is advantageous. Close collaboration with external partners increases knowledge and provides heterogeneous resources. Paired with digital awareness, this can lead to radical innovations [28]. For that reason, companies should be willing to collaborate and share their knowledge with external partners in a network that has a shared purpose $[9,31]$.

\subsection{Employee Participation, Agility and Organizational Structures}

A higher involvement of employees in decision making and more freedom might have a positive impact on the success of innovative projects [32]. Many others argue in the same way and say that employees should have more responsibilities, freedom and opportunities to participate in decision making $[9,10,22,26]$. This requires transparency and an open discussion of innovation initiatives and possible solutions $[26,40]$. Furthermore, the employees' involvement also helps to change their behavior. By empowering employees, companies can profit from enhanced innovation processes as well as from a faster ability to react to changes in the business environment. Additionally, mutual decision making helps to eliminate silos within the company [10]. 
According to [37], agility (defined as operational and strategic flexibility together with customer responsiveness) is crucial in order to adapt to changes in the business environment and to foster digital innovation culture.

\subsection{Error Culture and Risk-Taking}

In times of digital transformation, it is difficult to predict future changes in business environment. It needs courage to fight this uncertainty $[9,23]$.A willingness to take risks is essential for companies to explore new opportunities and to experiment in order to come up with new ideas $[27,40]$. Without taking risks, companies might miss a chance to create new innovations or to deliver them to the market. When exploring new things and taking risks, some projects might go wrong and failure might occur but where a risk is taken there is also the chance of new innovation. Instead of wasting resources for too long on corrupted projects, failures should be admitted [35].

\subsection{Internal Knowledge Sharing and Collaboration}

The creation of new ideas and an increased participation of employees in innovation initiatives demand for knowledge sharing and a closer collaboration within the company across all business units and hierarchical levels $[9,10,22,40]$. Therefore, the partly dominating silo mentality in companies must be abolished [26, 27, 39]. An integration of IT departments and business departments should especially be intended, as IT drives and enables digital transformation [10, 33, 35]. A close collaboration across business units also enables an identification of shared interests among employees and their special qualifications [26].

\subsection{Customer and Market Orientation}

Digital transformation might also have an impact on how companies create value. This characteristic addresses the customer orientation in value creation and companies' attention to changes in the market such as emerging technologies and competitors. Not reacting to market changes clearly makes digital transformation very difficult [35]. Some companies also fear losing their customers to competitors if they cannot offer the demanded digital products and services [10]. Therefore, customer centricity is crucial for businesses which means to address customer needs and align new products and services with them $[9,39]$. Some articles even go one step further and talk about customer integration or value co-creation. This means that customers are directly involved in innovation processes and work together on new products and services [10, $25,34]$. 


\subsection{Open-Mindedness and Willingness to Learn}

Digital transformation might cause and require radical changes. Whether a company deals with those changes successfully also depends on the attitude of their employees and their willingness to change and learn as well as their acceptance of new ideas.

Emerging technologies require open-mindedness and, as mentioned before, sometimes it is necessary to question the existing business model, assumptions and competencies $[22,25,28,35,36]$. Companies should encourage lateral thinking, outof-the-box thinking and curiosity $[38,40]$. According to most articles in this literature review, it is highly crucial that employees are open to change and willing to learn and develop [8, 10, 23, 25, 26, 32, 34, 35].

\section{Discussion and Implications for Future Research}

The characteristics outlined for fostering a digital innovation culture were synthesized on the basis of established papers and explained in more detail. Most of the identified articles do not explicitly focus on organizational culture and how it can foster digital innovations and even fewer articles specifically talk about digital innovation culture. However, all articles had at least some aspects regarding organizational culture that are related to our research question and helped us to identify the characteristics above. A broad and comprehensive framework that explicitly addresses most of these characteristics in a holistic approach is nonexistent. First attempts were delivered by [9] and [10].When we reviewed the papers, one discovery was that many articles dealt with the impact of digitization on national culture, the culture industry, as well as egovernment. Considerably fewer dealt directly about companies.

When comparing our derived characteristics to foster a digital innovation culture in organizations with relevant research on the culture of innovation in organizations, it is evident that they overlap in some areas.

For example, market orientation on the one hand and customer and market orientation on the other hand. At the same time, however [42] lacks a clear reference to corporate entrepreneurship, digital awareness, error culture and risk-taking as well as ecosystem orientation. All of which play a decisive role in the promotion of digital innovations. The following Table 2 compares [42] identified characteristics for fostering an Innovation Culture with our characteristics for fostering a digital innovation culture. 
Table 2. Comparison of Innovation Culture and Digital Innovation Culture Characteristics

\begin{tabular}{ll}
\hline Innovation Culture [42] & Digital Innovation Culture \\
\hline Innovation Propensity & Corporate Entrepreneurship \\
Organizational Constituency & Employee Participation, Agility and \\
& Organizational Structures \\
Creative and Empowerment & Error Culture and Risk-Taking \\
Organizational Learning & Open-Mindedness and Willingness to \\
& Learn \\
Market Orientation & Customer and Market Orientation \\
Value Orientation & Customer and Market Orientation \\
Implementation Context & - \\
- & Ecosystem Orientation \\
- & Digital Awareness and Necessity of \\
- & Innovations \\
- & Digital Skills and Resources \\
& Internal Knowledge Sharing and \\
\hline
\end{tabular}

The following Table 3 gives a summary of the characteristics and why each of them should receive more attention in order to foster digital innovations in organizations. More questions regarding further research could address the concrete design of these characteristics and how they can be managed and implemented in corporate practice. Additionally, the correlation among the identified characteristics should be investigated. The importance of particular characteristics might vary and should be object of future research.

Companies from the "old world", whose current focus or core competences are not associated with digital innovation, might especially profit from a framework that helps to transform the organizational culture and foster digital innovations. This problem should be considered in future studies. Appropriate questions for each characteristic were developed as a first step towards creating such a framework (Table 3). 
Table 3. Characteristics, Digital Relevance and Future Research Questions

\begin{tabular}{|c|c|c|}
\hline Characteristic & Digital Relevance & Future Research Questions \\
\hline $\begin{array}{l}\text { Corporate } \\
\text { Entrepreneurship }\end{array}$ & $\begin{array}{l}\text { Enhance proactivity; } \\
\text { foster idea generation and } \\
\text { innovations }\end{array}$ & $\begin{array}{l}\text { What skills should a corporate } \\
\text { entrepreneur have to create } \\
\text { digital innovations? }\end{array}$ \\
\hline $\begin{array}{l}\text { Digital } \\
\text { Awareness and } \\
\text { Necessity of } \\
\text { Innovations }\end{array}$ & $\begin{array}{l}\text { Justifies upcoming } \\
\text { changes and explains the } \\
\text { need for innovations }\end{array}$ & $\begin{array}{l}\text { How can companies achieve this } \\
\text { awareness and create a common } \\
\text { understanding? }\end{array}$ \\
\hline $\begin{array}{l}\text { Digital Skills and } \\
\text { Resources }\end{array}$ & $\begin{array}{l}\text { Especially IT related skills } \\
\text { are required }\end{array}$ & $\begin{array}{l}\text { How should companies evaluate } \\
\text { their competencies and identify } \\
\text { missing skills? }\end{array}$ \\
\hline $\begin{array}{l}\text { Ecosystem } \\
\text { Orientation }\end{array}$ & $\begin{array}{l}\text { Necessary to create } \\
\text { innovative end-to-end } \\
\text { solutions for customer }\end{array}$ & $\begin{array}{l}\text { How can a company find } \\
\text { appropriate partners and } \\
\text { integrate them in a digital } \\
\text { ecosystem? }\end{array}$ \\
\hline $\begin{array}{l}\text { Employee } \\
\text { Participation, } \\
\text { Agility and } \\
\text { Organizational } \\
\text { Structures }\end{array}$ & $\begin{array}{l}\text { Fast changes in business } \\
\text { environment require } \\
\text { agility, flexibility and fast } \\
\text { decision making }\end{array}$ & $\begin{array}{l}\text { How should companies deal with } \\
\text { radical innovations and } \\
\text { disruptive technologies? Is it } \\
\text { possible to avoid spin-offs? }\end{array}$ \\
\hline $\begin{array}{l}\text { Error Culture and } \\
\text { Risk-Taking }\end{array}$ & $\begin{array}{l}\text { Enhance proactivity; } \\
\text { promote learning; } \\
\text { encourage experiments } \\
\text { (e.g. with new } \\
\text { technologies) and efficient } \\
\text { innovations }\end{array}$ & $\begin{array}{l}\text { What general conditions do } \\
\text { companies have to meet in order } \\
\text { to encourage experiments and } \\
\text { change employees' minds as } \\
\text { well as their behavior? }\end{array}$ \\
\hline $\begin{array}{l}\text { Internal } \\
\text { Knowledge } \\
\text { Sharing and } \\
\text { Collaboration }\end{array}$ & $\begin{array}{l}\text { Cross-functional } \\
\text { collaboration fosters } \\
\text { digital innovations and } \\
\text { creates synergies }\end{array}$ & $\begin{array}{l}\text { How can companies abolish silos } \\
\text { and create a collaborative } \\
\text { climate across business units? } \\
\text { How can this knowledge } \\
\text { exchange be managed and } \\
\text { recorded? }\end{array}$ \\
\hline $\begin{array}{l}\text { Customer and } \\
\text { Market } \\
\text { Orientation }\end{array}$ & $\begin{array}{l}\text { Ensure customer value; } \\
\text { data analytics enable new } \\
\text { services and business } \\
\text { models }\end{array}$ & $\begin{array}{l}\text { How can companies manage the } \\
\text { balancing act between market- } \\
\text { pull and innovation-push? }\end{array}$ \\
\hline $\begin{array}{l}\text { Open- } \\
\text { Mindedness and } \\
\text { Willingness to } \\
\text { Learn }\end{array}$ & $\begin{array}{l}\text { Learning is crucial for the } \\
\text { success of digital } \\
\text { transformation; new } \\
\text { methods, skills and } \\
\text { partners are needed which } \\
\text { requires open-mindedness }\end{array}$ & $\begin{array}{l}\text { This long-lasting and radical } \\
\text { change in employees' minds is } \\
\text { difficult to accomplish. How can } \\
\text { companies establish this new } \\
\text { way of thinking? }\end{array}$ \\
\hline
\end{tabular}




\section{Conclusion and Limitations}

Innovations are crucial for companies to manage digital transformation successfully. The organizational culture of a company has a great impact on the creation of these digital innovations. The contribution of this paper is novel and relevant for research and practice. The established research question has been answered by identifying and describing characteristics of organizational culture that foster digital innovations on the basis of established literature. At the same time, the term "Digital Innovation Culture" was introduced to emphasize the importance of such a cultural approach to digital transformation and innovation.

However, there are also limiting aspects regarding the results for several reasons. First, the findings are limited to the articles that were taken into account for this literature review. The selected scholarly databases as well as our key word search and literature selection restrict the list of articles in a certain and a subjective way that we are aware of. Second, it is possible to cluster the key aspects of the relevant articles in other ways. Therefore, our identified characteristics might neither be perfect nor do we claim their completeness.

Based on the insights of this paper, empirical research in companies can help to elaborate the characteristics, to conceptualize digital innovation culture and to identify management challenges in this area.

\section{References}

1. Bradley, J., Loucks, J., Macaulay, J., Noronha, A., Wade, M.: Digital Vortex. How Digital Disruption Is Redefining Industries. Global Center for Digital Business Transformation, Lausanne (2015)

2. Kao, J.J.: The art \& discipline of business creativity. Strategy \& Leadership 25, 6-11 (1997)

3. Tushman, M.L.: Winning through innovation. Strategy \& Leadership 25, 14-19 (1997)

4. Rujirawanich, P., Addison, R., Smallman, C.: The effects of cultural factors on innovation in a Thai SME. Management Research Review 34, 1264-1279 (2011)

5. Tian, M., Deng, P., Zhang, Y., Salmador, M.P.: How does culture influence innovation? A systematic literature review. Management Decision 56, 1088-1107 (2018)

6. Fitzgerald, M., Kruschwitz, N., Bonnet, D., Welch, M.: Embracing digital technology. A new strategic imperative. MIT Sloan Management Review (2013)

7. Westerman, G., Bonnet, D., McAfee, A.: Leading Digital. Harvard Business Publishing, Boston (2014)

8. Nambisan, S., Lyytinen, K., Majchrzak, A., Song, M.: Digital Innovation Management: Reinventing Innovation Management Research in a Digital World. Management Information Systems Quarterly 41, 223-238 (2017)

9. Hartl, E., Hess, T.: The Role of Cultural Values for Digital Transformation. Insights from a Delphi Study. In: 23rd Americas Conference on Information Systems. AMCIS 2017, pp. 110. Association for Information Systems, Atlanta, USA (2017)

10. Duerr, S., Holotiuk, F., Wagner, H.-T., Beimborn, D., Weitzel, T.: What Is Digital Organizational Culture? Insights From Exploratory Case Studies. In: Bui, T. (ed.) 51st Hawaii International Conference on System Sciences. HICSS 2018, pp. 1-10. AIS Electronic Library, Hawaii, USA (2018) 
11. Wiedmann, K.-P., Lippold, A., Buxel, H.: Status quo der theoretischen und empirischen Innovationskulturforschung sowie Konstruktkonzeptualisierung des Phänomens Innovationskultur. der markt - International Journal of Marketing 47, 43-60 (2008)

12. Wokurka, G., Banschbach, Y., Houlder, D., Jolly, R.: Digital Culture. Why Strategy and Culture Should Eat Breakfast Together. In: Oswald, G., Kleinemeier, M. (eds.) Shaping the Digital Enterprise. Trends and Use Cases in Digital Innovation and Transformation, pp. 109-120. Springer, Cham (2017)

13. Schein, E.H.: Organizational culture and leadership. John Wiley \& Sons, New Jersey, USA (2004)

14. Benner, M.J., Tushman, M.L.: Reflections on the 2013 Decade Award-“Exploitation, Exploration, and Process Management: The Productivity Dilemma Revisited" Ten Years Later. AMR 40, 497-514 (2015)

15. Libert, B., Beck, M., Wind, Y.: 7 Questions to Ask Before Your Next Digital Transformation. Harvard Business Review (2016)

16. Yoo, Y., Lyytinen, K.J., Boland, R.J., Berente, N.: The Next Wave of Digital Innovation: Opportunities and Challenges. A Report on the Research Workshop 'Digital Challenges in Innovation Research. SSRN Journal, 1-37 (2010)

17. Brocke, J. vom, Cleven, A., Niehaves, B., Plattfaut, R., Riemer, K., Simons, A.: Reconstructing the Giant. On the Importance of Rigour in Documenting the Literature Search Process. In: Newell, S., Whitley, E.A., Pouloudi, N., Wareham, J., Mathiassen, L. (eds.) 17th European Conference on Information Systems. ECIS 2009, pp. 2206-2217. Association for Information Systems, Atlanta, USA (2009)

18. Frost, R., Lyons, K.: Service Systems Analysis Methods and Components. A Systematic Literature Review. Service Science 9, 219-234 (2017)

19. Wolfswinkel, J.F., Furtmueller, E., Wilderom, C.P.M.: Using grounded theory as a method for rigorously reviewing literature. European Journal of Information Systems 22, 45-55 (2013)

20. Okoli, C., Schabram, K.: A Guide to Conducting a Systematic Literature Review of Information Systems Research. SSRN Journal (2010)

21. Bandara, W., Miskon, S., Fielt, E.: A systematic, tool-supported method for conducting literature reviews in information systems. In: 19th European Conference on Information Systems. ECIS 2011, p. 221. Association for Information Systems, Atlanta, USA (2011)

22. Karimi, J., Walter, Z.: Corporate Entrepreneurship, Disruptive Business Model Innovation Adoption, and Its Performance. The Case of the Newspaper Industry. Long Range Planning 49, 342-360 (2016)

23. Billington, M., Ellersgaard, B.: Unleashing Disruptive Leadership - Teaching Carpe Diem! Business Education Innovation Journal 9, 133-138 (2017)

24. Bleicher, J., Stanley, H.: Digitization as a Catalyst for Business Model Innovation a ThreeStep Approach to Facilitating Economic Success. Journal of Business Management, 62-71 (2016)

25. Rosa, S.C. da, Schreiber, D., Schmidt, S., Júnior, N.: Management practices that combine value cocreation and user experience. An Analysis of the Nubank Startup in the Brazilian Market. Revista de Gestão, Finanças e Contabilidade 7, 22-43 (2017)

26. Dahl, A., Lawrence, J., Pierce, J.: Building an Innovation Community. Research Technology Management 54, 19-27 (2011)

27. Frishammar, J., Richtnér, A., Brattström, A., Magnusson, M., Björk, J.: Opportunities and challenges in the new innovation landscape. Implications for innovation auditing and innovation management. European Management Journal 37, 151-164 (2019) 
28. Goduscheit, R.C., Faullant, R.: Paths Toward Radical Service Innovation in Manufacturing Companies. A Service-Dominant Logic Perspective. Journal of Product Innovation Management 35, 701-719 (2018)

29. Govindarajan, V., Trimble, C.: Organizational DNA for Strategic Innovation. California Management Review 47, 47-76 (2005)

30. Ho, J.C., Chen, H.: Managing the Disruptive and Sustaining the Disrupted. The Case of Kodak and Fujifilm in the Face of Digital Disruption. Review of Policy Research 35, 352371 (2018)

31. Igartua, I.J., Retegi, J., Ganzarain, J.: IM2, a Maturity Model for Innovation in SMEs. Dirección y Organización, 42-49 (2018)

32. Karimi, J., Walter, Z.: The Role of Dynamic Capabilities in Responding to Digital Disruption. A Factor-Based Study of the Newspaper Industry. Journal of Management Information Systems 32, 39-81 (2015)

33. Kayser, V., Nehrke, B., Zubovic, D.: Data Science as an Innovation Challenge. From Big Data to Value Proposition. Journal of Technology Management and Innovation 8, 16-25 (2018)

34. Luo, J., van de Ven, A., Jing, R., Jiang, Y.: Transitioning from a hierarchical product organization to an open platform organization. A Chinese case study. Journal of Organization Design 7, 1-14 (2018)

35. Neus, A., Buder, F., Galdino, F.: Are You Too Successful to Digitalize? How to Fight Innovation Blindness. GfK-Marketing Intelligence Review 9, 31-35 (2017)

36. Quinton, S., Canhoto, A., Molinillo, S., Pera, R., Budhathoki, T.: Conceptualising a digital orientation. antecedents of supporting SME performance in the digital economy. Journal of Strategic Marketing 26, 427-439 (2018)

37. Ravichandran, T.: Exploring the relationships between IT competence, innovation capacity and organizational agility. The Journal of Strategic Information Systems 27, 22-42 (2018)

38. Sousa, M.J., Wilks, D.: Sustainable Skills for the World of Work in the Digital Age. Systems Research and Behavioral Science 35, 399-405 (2018)

39. Troilo, G., Luca, L.M. de, Guenzi, P.: Linking Data-Rich Environments with Service Innovation in Incumbent Firms. A Conceptual Framework and Research Propositions. Journal of Product Innovation Management 34, 617-639 (2017)

40. Vey, K., Fandel-Meyer, T., Zipp, J.S., Schneider, C.: Learning \& Development in Times of Digital Transformation. Facilitating a Culture of Change and Innovation. International Journal of Advanced Corporate Learning 10, 22-32 (2017)

41. Zeng, J., Glaister, K.W.: Value creation from big data: Looking inside the black box. Strategic Organization 16, 105-140 (2018)

42. Dobni, C.B.: Measuring innovation culture in organizations. European Journal of Innovation Management 11, 539-559 (2008) 